\title{
Tomato New Sapogenols, Isoesculeogenin A and Esculeogenin B
}

\author{
Miho Yoshizaki, ${ }^{a}$ Sayaka Matsushita,${ }^{a}$ Yukio Fujiwara, ${ }^{a}$ Tsuyoshi Ikeda, ${ }^{a}$ Masateru Ono, ${ }^{b}$ and \\ Toshihiro NOHARA ${ }^{*, a}$ \\ ${ }^{a}$ Faculty of Medical and Pharmaceutical Science, Kumamoto University; 5-1 Oe-honmachi, Kumamoto 862-0973, Japan: \\ and ${ }^{b}$ School of Agriculture, Kyushu Tokai University; 5435 Choyo, Aso, Kumamoto 869-1404, Japan. \\ Received January 24, 2005; accepted March 22, 2005
}

\begin{abstract}
Two novel sapogenols, isoesculeogenin A (1) and esculeogenin B (2) of steroidal alkaloid glycosides, lycoperoside $F$ and esculeoside $B$, respectively, isolated from the ripe tomato have been characterized as $(5 \alpha, 22 R, 23 R, 25 S)-3 \beta, 23,27-t r i h y d r o x y s p i r o s o l a n e ~ a n d ~(5 \alpha, 22 S, 23 R, 25 S)-22,26$-epimino-16 $\beta, 23-e p o x y-3 \beta, 23,27-$ trihydroxycholestane, respectively.
\end{abstract}

Key words Lycopersicon esculentum; tomato; steroidal alkaloid sapogenol; spirosolane; solanocapsine

Tomato, the fruit of Lycopersicon esculentum MiLL., is widely used as a fresh vegetable and in cooking. The species of tomato found in markets can be roughly classified into two groups, the red color-type and pink color-type; the red colortype tomato (e.g. Italian San Marzano) is mainly used for pasta sauce and in cooking, and the pink color-type tomato (e.g. Momotaro) as a fresh vegetable. The tomato has received much attention due to the presence of lycopene which has having strong anti-oxidant activity. Recently, we isolated a new major spirosolane-type glycoside, named esculeoside $\mathrm{A}^{1,2)}$ from the fruit of a Cherry tomato [L. esculentum var. cerasiforme (DUNAL) ALEF.] and the pink color-type tomato, and a novel major solanocapsine-type glycoside, named esculeoside $\mathrm{B},{ }^{2)}$ from the red color-type tomato. The sapogenol, esculeogenin $\mathrm{A},{ }^{1,2)}$ was obtained in a crystalline state by acid hydrolysis of esculeoside $\mathrm{A}$ and characterized as (5 $\alpha, 22 S, 23 S, 25 S)-3 \beta, 23,27$-trihydroxyspirosolane. In order to confirm the structures of their new sapogenols and to investigate the bio-activities of their sapogenols, two novel sapogenols, isoesculeogenin A (1) and esculeogenin B (2) have been obtained by acid hydrolysis of lycoperoside $\mathrm{F}^{3)}(\mathbf{3})$ and by enzymic hydrolysis of esculeoside $\mathrm{B},{ }^{2)}$ respectively, and their structures have been established.

Acid hydrolysis of lycoperoside F (3), obtained from the ripe fruits of Meddy Red tomato as a major glycoside, with $2 \mathrm{~N} \mathrm{HCl}-\mathrm{MeOH}$ provided a new sapogenol, named as isoesculeogenin A (1), as colorless needles with mp $206-213^{\circ} \mathrm{C}$, $[\alpha]_{\mathrm{D}}-87.2^{\circ}$ (pyridine). Its high resolution (HR)-EI-MS indicated a molecular ion at $\mathrm{m} / z 447.3367$ due to $\left[\mathrm{C}_{27} \mathrm{H}_{45} \mathrm{NO}_{4}\right.$, $\mathrm{M}]^{+}$being identical with that of esculeogenin $\mathrm{A}$. The ${ }^{1} \mathrm{H}$-detected heteronuclear multiple-bond correlation (HMBC) spectrum of $\mathbf{1}$ as illustrated in Fig. 1 revealed that $\mathbf{1}$ is a spirosolane derivative with hydroxyl groups at C-23 and C27. The above evidence suggested $\mathbf{1}$ is an isomer of esculeogenin A. By comparing the ${ }^{1} \mathrm{H}-\mathrm{NMR}$ signals (pyridine- $d_{5}$ ) with those of esculeogenin $\mathrm{A}$, they were assigned as follows: two quaternary methyl signals at $\delta 0.80\left(3 \mathrm{H}, \mathrm{s}, \mathrm{H}_{3}-\right.$ 19), $0.95\left(3 \mathrm{H}, \mathrm{s}, \mathrm{H}_{3}-18\right)$, one secondary methyl signal at $\delta$ $1.54\left(3 \mathrm{H}, \mathrm{d}, J=6.8 \mathrm{~Hz}, \mathrm{H}_{3}-21\right)$, which was shifted toward a lower field than that of esculeogenin A by $0.47 \mathrm{ppm}$, two proton signals of a nitrogen-bearing methylene group at $\delta 3.17$ $\left(2 \mathrm{H}, \mathrm{m}, \mathrm{H}_{2}-26\right)$, one hydroxymethyl proton signal at $\delta 3.73$ $\left(2 \mathrm{H}, \mathrm{m}, \mathrm{H}_{2}-27\right)$, three proton signals of an oxygen-bearing methine group at $\delta 3.80(1 \mathrm{H}, \mathrm{m}, \mathrm{H}-3), 4.28(1 \mathrm{H}, \mathrm{dd}, J=3.0$,
$10.0 \mathrm{~Hz}, \mathrm{H}-23)$, and $5.29(1 \mathrm{H}, \mathrm{m}, \mathrm{H}-16)$, which is also lowershifted by $0.80 \mathrm{ppm}$ by comparing with that of esculeogenin A. The lower shifts of $\mathrm{H}_{3}-21$ and $\mathrm{H}-16$ suggested that they are close to the C-23 hydroxyl group, therefore, the configuration at $\mathrm{C}-22$ could be estimated as $22 \beta N$, that is $22 R$. This conclusion was also supported by the chemical shift at C20 . $^{4)}$ In $22 \alpha N$-spirosolane derivatives, the C-20 signals appeared around $\delta 35.0$, while in $22 \beta N$-series (C-22R), it occurred around $\delta$ 43.0. Isoesculeogenin A (1) appeared at $\delta$ 44.1 , suggesting the configuration at $\mathrm{C}-22$ to be $\mathrm{C}-22 \beta N$ (C$22 R$ ). The hydroxyl group at $\mathrm{C}-23$ was estimated as equator$i a l$, namely $\mathrm{C}-23 R$, based on the coupling constant of $\mathrm{H}-23$ $(1 \mathrm{H}, \mathrm{dd}, J=3.0,10.0 \mathrm{~Hz}$, at $\delta 4.27)$. Moreover, the C-27-hydroxymethyl group was also judged to be equatorial, C-25S, from the evidence of the coupling pattern of the C-26 methylene protons at $\delta 3.17\left(2 \mathrm{H}, \mathrm{m}, \mathrm{H}_{2}-26\right)$, which were apparently different from those $[1 \mathrm{H}, \mathrm{d}, J=11.0 \mathrm{~Hz}, \mathrm{Hax}-26$, at $\delta 3.05$ and $1 \mathrm{H}, \mathrm{dd}, J=3.4,11.0 \mathrm{~Hz}, \mathrm{Heq}-26$, at $\delta 3.34]$ of esculeogenin A. Other carbon signals were coincident with those at $\mathrm{C}-1-14$ of esculeogenin A. Consequently, the structure of 1 was $(5 \alpha, 22 R, 23 R, 25 S)$-3 $\beta, 23,27$-trihydroxyspirosolane.

Next, esculeogenin B (2) was obtained by enzymic hydrolysis; that is, firstly esculeoside B was enzymic-hydrolyzed with tomatinase ${ }^{5)}$ to give a prosapogen (4), which was subsequently subjected to an analogous enzymic hydrolysis with $\beta$-glucosidase to provide a sapogenol, named as esculeogenin B (2), as an amorphous powder showing $[\alpha]_{\mathrm{D}}-96.2^{\circ}$ (pyridine). The HR-EI-MS of 2 showed a peak at $\mathrm{m} / \mathrm{z} 447.3298$ corresponding to a molecular formula $\left[\mathrm{C}_{27} \mathrm{H}_{45} \mathrm{NO}_{4}, \mathrm{M}\right]^{+}$. The ${ }^{1} \mathrm{H}-\mathrm{NMR}$ spectrum (in pyridine- $d_{5}$ ) showed two tertiary methyl signals at $\delta 0.81$ and 1.01 , one secondary methyl sig-

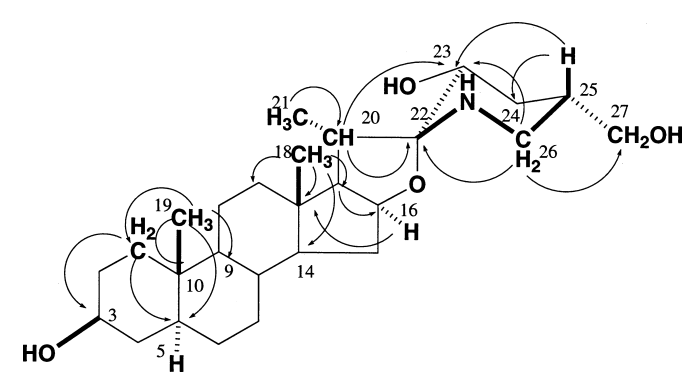

Fig. 1. Key HMBC Observed in Isoesculeogenin A (1) 


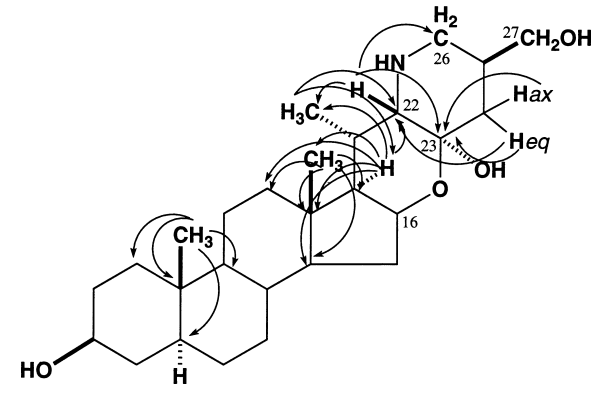

Fig. 2. Key HMBC Observed in Esculeogenin B (2)

nal at $\delta 1.67(\mathrm{~d}, J=6.7 \mathrm{~Hz})$, two nitrogen-bearing methylene protons at $\delta 3.02(1 \mathrm{H}, \mathrm{t}$-like, $J=12.1 \mathrm{~Hz})$ and $3.30(1 \mathrm{H}, \mathrm{brd}$, $J=12.1 \mathrm{~Hz})$, two hydroxymethyl protons at $\delta 3.73(2 \mathrm{H}, \mathrm{d}$, $J=6.7 \mathrm{~Hz}$ ), and two oxygen-bearing methine protons at $\delta 3.85(1 \mathrm{H}, \mathrm{m})$ and $4.63(1 \mathrm{H}, \mathrm{m})$. The ${ }^{13} \mathrm{C}$-NMR signals (in pyridine- $d_{5}$ ) displayed a total of twenty-seven carbon signals comprised of three methyls $(\delta 12.6,15.4,17.8)$, one hydroxymethyl ( $\delta 65.4)$, one hemiketal carbon $(\delta 96.8)$, one nitrogen-bearing methine carbon $(\delta 63.0)$, one nitrogen-bearing methylene carbon $(\delta$ 43.8), and two oxygen-bearing methine carbons $(2 \times \delta 70.6)$. By the aid of proton-proton chemical shift correlated spectroscopy $\left({ }^{1} \mathrm{H}-{ }^{1} \mathrm{H}-\mathrm{COSY}\right),{ }^{1} \mathrm{H}-$ detected heteronuclear correlation through multiple quantum coherence (HMQC) and $\mathrm{HMBC}$, all of the carbon signals of 2 were assigned as follows: C- $1-27$ of sapogenol: $\delta 37.6$, $32.1,70.6,39.3,45.4,29.1,32.6,35.3,54.8,35.9,21.4,40.7$, $42.1,53.6,33.8,70.6,62.7,15.4,12.6,27.6,17.8,63.0,96.8$, $39.3,25.2,43.8,65.4$. On this assignment, especially, the HMBC between $\mathrm{H}_{3}-21$ and C-22 as illustrated in Fig. 2, and the occurrence of the hemiketal carbon function conclusively characterized a novel sapogenol moiety, which has a rare natural product, solanocapsine-type framework. ${ }^{6,7)}$ Next, NOESY led to the assignments of the configurations at C-22 and C-23. Namely, the observation of NOESY between H-20 and $\mathrm{H}-22$, and between $\mathrm{H}-26$ and $\mathrm{H}-22$ revealed the configurations of both $\mathrm{H}-20$ and $\mathrm{H}-22$ to be cis-correlation. The configuration of the hydroxymethyl group at C-25 was also deduced to be equatorial on the basis of the coupling constants of $\mathrm{H}_{2}-26$ signals at $\delta 3.02(1 \mathrm{H}$, t-like, $J=12.1 \mathrm{~Hz}, \mathrm{Hax}-26)$, $3.30(1 \mathrm{H}, \mathrm{brd}, J=12.1 \mathrm{~Hz}, \mathrm{Heq}-26)$. The configuration of the hydroxyl group at $\mathrm{C}-23$ was estimated as $\alpha$-axial based on the fact that $\mathrm{H}_{3}-21$ signals shifted toward a lower field at $\delta 1.67$ in a 1,3-diaxial correlation with the $\mathrm{C}-23-\mathrm{OH}$ group. Consequently, the structure of 2 could be represented as $(5 \alpha, 22 S, 23 R, 25 S)$-22,26-epimino-16 $\beta, 23$-epoxy-3 $\beta, 23,27$ trihydroxycholestane.

\section{Experimental}

General Procedure Melting points were determined on a Yanagimoto micromelting point apparatus without correction. Optical rotations were measured on a JASCO DIP-1000 KUY digital polarimeter $(l=0.5)$. NMR spectra were measured in pyridine- $d_{5}$ on a JEOL $\alpha-500$ spectrometer and chemical shifts were referenced to TMS. HR-EI-MS were obtained with a JEOL JMS-MS-700 spectrometer. Column chromatography was carried out with silica gel $60(0.063-0.200 \mathrm{~mm}$, Merck), Diaion HP-20P (Mitsubishi Chemical Industries Co., Ltd.) and Chromatorex ODS (Fuji Silysia Chemical Co., Ltd.), and TLC was performed on a precoated silica gel $60 \mathrm{~F}_{254}$ (Merck) and RP-18 $\mathrm{F}_{254} \mathrm{~S}$ (Merck), and detected by spraying with $10 \%$ $\mathrm{H}_{2} \mathrm{SO}_{4}$ in $50 \% \mathrm{MeOH}$, followed by heating on a hot plate. The HPLC system consisted of a pump (Hitachi C-6000), detector (JASCO 830-RI), column [Kanto Chem. Co. Mightysil RP-18GP 250-4.6 (5mm)], and mobile phase ( $60 \% \mathrm{MeOH}$; flow rate, $0.8 \mathrm{ml} / \mathrm{min}$.).

Isolation of Lycoperoside F (3) Meddy Red tomatoes (762 g) were smashed in water and then filtered to give a filtrate, which was passed through Diaion HP-20P and eluted with water and then $\mathrm{MeOH}$. The $\mathrm{MeOH}$ eluate $(1.42 \mathrm{~g})$ was chromatographed on ODS with a $40 \% \mathrm{MeOH}-60 \%$ $\mathrm{MeOH}-\mathrm{MeOH}$ gradient to give three fractions. A part $(23 \mathrm{mg})$ of fraction 3 $(320.8 \mathrm{mg})$ was subjected to HPLC to provide esculeoside A $(5 \mathrm{mg})$ and lycoperoside $\mathrm{F}(3,9 \mathrm{mg})$. Colorless amorphous powder, $[\alpha]_{\mathrm{D}}-44.8^{\circ}(c=0.75$, pyridine). Positive HR-FAB-MS $(\mathrm{m} / \mathrm{z}) 1292.5872$ (Calcd for $\mathrm{C}_{58} \mathrm{H}_{95} \mathrm{NO}_{29} \mathrm{Na}$, $1292.5888\left[\mathrm{M}+\mathrm{Na}^{+}\right] .{ }^{1} \mathrm{H}-\mathrm{NMR}$ (pyridine- $\left.d_{5}\right) \delta: 0.66\left(3 \mathrm{H}, \mathrm{s}, \mathrm{H}_{3}-19\right), 0.88$ $\left(3 \mathrm{H}, \mathrm{s}, \mathrm{H}_{3}-18\right), 1.18\left(3 \mathrm{H}, \mathrm{d}, J=6.7 \mathrm{~Hz}, \mathrm{H}_{3}-21\right), 2.23(3 \mathrm{H}, \mathrm{s}$, acetyl $), 4.74(1 \mathrm{H}$, d, $J=7.9 \mathrm{~Hz}$, gal H-1), $4.91(1 \mathrm{H}, \mathrm{d}, J=7.9 \mathrm{~Hz}, 27-O-$ glc $\mathrm{H}-1), 5.12(1 \mathrm{H}$, d, $J=7.9 \mathrm{~Hz}$, inner glc $\mathrm{H}-1), 5.16(1 \mathrm{H}, \mathrm{d}, J=7.9 \mathrm{~Hz}$, xyl H-1 $), 5.55(1 \mathrm{H}, \mathrm{d}$, $J=7.9 \mathrm{~Hz}$, term. glc $\mathrm{H}-1$ ). ${ }^{13} \mathrm{C}-\mathrm{NMR}$ (pyridine- $d_{5}$ ), sapogenol C-1-27: $\delta$ $36.9,29.5,77.9,35.1,44.7,28.6,32.0,35.5,54.2,35.0,21.2,40.1,41.1$, $56.2,34.4,82.4,63.2,17.0,12.0,42.9,15.2,100.5,74.9,32.0,36.9,44.7$, 72.5 , OAc: $21.8,170.2$, gal C-1 -6: 102.0, 73.0, 74.9, 79.1, 74.6, 61.8, inner glc C-1—6: 104.3, 80.4, 86.7, 70.4, 77.2, 62.2, terminal glc C-1—6: 103.9, $76.8,77.9,71.2,77.9,62.2$, xyl C-1-5: 104.3, 75.3, 77.6, 70.1, 66.6, 27-Oglc C-1—6: 104.1, 74.9, 79.1, 71.1, 77.9, 63.2.

Isoesculeogenin A (1) After lycoperoside F (3,124 mg) was hydrolyzed with $2 \mathrm{~N} \mathrm{HCl}(3 \mathrm{ml})$, the reaction mixture was extracted with AcOEt. The organic layer was evaporated in vacuo to afford a residue which was purified by silica gel column chromatography with $\mathrm{CHCl}_{3}-\mathrm{MeOH}$-water $=9: 1: 0.1$ to give isoesculeogenin A $(\mathbf{1}, 9 \mathrm{mg})$. Colorless needles, $\mathrm{mp} 206-213^{\circ} \mathrm{C}$, $[\alpha]_{\mathrm{D}}-87.2^{\circ}\left(c=0.64\right.$, pyridine), HR-EI-MS $(\mathrm{m} / \mathrm{z}): 447.3367[\mathrm{M}]^{+}(\mathrm{Calcd}$ for $\mathrm{C}_{27} \mathrm{H}_{45} \mathrm{NO}_{4}$ : 447.3349; ${ }^{1} \mathrm{H}-\mathrm{NMR}$ (pyridine- $\left.d_{5}\right) \delta: 0.80\left(3 \mathrm{H}, \mathrm{s}, \mathrm{H}_{3}-19\right)$, $0.95\left(3 \mathrm{H}, \mathrm{s}, \mathrm{H}_{3}-18\right), 1.54\left(3 \mathrm{H}, \mathrm{d}, J=6.8 \mathrm{~Hz}, \mathrm{H}_{3}-21\right), 3.17\left(2 \mathrm{H}, \mathrm{m}, \mathrm{H}_{2}-26\right)$, $3.73\left(2 \mathrm{H}, \mathrm{m}, \mathrm{H}_{2}-27\right), 3.80(1 \mathrm{H}, \mathrm{m}, \mathrm{H}-3), 4.28(1 \mathrm{H}, \mathrm{dd}, J=3.0,10.0 \mathrm{~Hz}, \mathrm{H}-$ 23), $5.29(1 \mathrm{H}, \mathrm{m}, \mathrm{H}-16) .{ }^{13} \mathrm{C}-\mathrm{NMR}$ (pyridine- $d_{5}$ ), $\mathrm{C}-1-27: \delta 37.5,32.3$, 70.6, 39.2, 45.2, 29.1, 32.6, 35.3, 54.8, 35.9, 21.5, 40.7, 40.1, 56.7, 34.3, 82.7, 63.7, 17.3, 12.5, 44.1, 16.5, 102.5, 72.2, 32.4, 35.3, 45.9, 65.6.

Prosapogenin (4) A mixture of esculeoside B $(96 \mathrm{mg})$ and tomatinase $(5 \mathrm{ml})$ in citric acid buffer $(12 \mathrm{ml})$ was left to stand at r.t. for $1 \mathrm{~d}$. After filtration, the filtrate was passed through a Diaion HP-20 column with water and then $\mathrm{MeOH}$. The $\mathrm{MeOH}$ eluate was subjected to silica gel column chromatography with $\mathrm{CHCl}_{3}-\mathrm{MeOH}$-water $=9: 1: 0.1 \rightarrow 7: 3: 0.5$ to give prosapogenin $\left(18 \mathrm{mg}\right.$ ). An amorphous powder, ${ }^{13} \mathrm{C}-\mathrm{NMR}$ (pyridine- $d_{5}$ ), Sapogenol moiety $\mathrm{C}-1-27$ : $\delta 37.6,32.5,70.6,39.3,45.3,29.1,32.6,35.3,54.8,35.9$, $21.4,37.7,42.1,53.6,33.7,70.6,62.4,15.4,12.6,27.6,17.7,63.0,96.4$, 40.7, 29.9, 43.7, 72.7; 27-O-Glucosyl moiety $\mathrm{C}-1-6: 104.7,75.2,78.5$, 71.8, 78.6, 63.0.

Esculeogenin B (2) A mixture of prosapogenin $(13 \mathrm{mg})$ and $\beta$-glucosidase in citric acid buffer $(4 \mathrm{ml})$ was incubated for one day at $38^{\circ} \mathrm{C}$. After the reaction mixture was filtered and washed with $\mathrm{MeOH}$, the filtrate was passed through a Diaion HP-20 column first with water and then $\mathrm{MeOH}$. The $\mathrm{MeOH}$ eluate was subjected to silica gel column chromatography with $\mathrm{CHCl}_{3}-\mathrm{MeOH}$-water $=9: 1: 0.1 \rightarrow 8: 2: 0.5$ to give esculeogenin $\mathrm{B}$ (2, $6 \mathrm{mg})$, an amorphous powder, $[\alpha]_{\mathrm{D}}-96.2^{\circ}(c=0.05$, pyridine), HR-EI-MS $(\mathrm{m} / \mathrm{z}): 447.3298[\mathrm{M}]^{+}$(Calcd for $\mathrm{C}_{27} \mathrm{H}_{45} \mathrm{NO}_{4}: 447.3349 ;{ }^{1} \mathrm{H}-\mathrm{NMR}$ (pyridine$\left.d_{5}\right) \delta 0.81\left(3 \mathrm{H}, \mathrm{s}, \mathrm{H}_{3}-19\right), 1.01\left(3 \mathrm{H}, \mathrm{s}, \mathrm{H}_{3}-18\right), 1.67\left(3 \mathrm{H}, \mathrm{d}, J=6.7 \mathrm{~Hz}, \mathrm{H}_{3}-\right.$ 21), $3.02(1 \mathrm{H}, \mathrm{t}-\mathrm{like}, J=12.1 \mathrm{~Hz}, \mathrm{Hax}-26), 3.30(1 \mathrm{H}, \mathrm{brd}, J=12.1 \mathrm{~Hz}$, Heq26), $3.73\left(2 \mathrm{H}, \mathrm{d}, J=6.7 \mathrm{~Hz}, \mathrm{H}_{2}-27\right), 3.85(1 \mathrm{H}, \mathrm{m}, \mathrm{H}-3), 4.63(1 \mathrm{H}, \mathrm{m}, \mathrm{H}-16)$. ${ }^{13} \mathrm{C}-\mathrm{NMR}$ (pyridine- $d_{5}$ ), C-1-27: $\delta 37.6,32.1,70.6,39.3,45.4,29.1,32.6$, $35.3,54.8,35.9,21.4,40.7,42.1,53.6,33.8,70.6,62.7,15.4,12.6,27.6$, $17.8,63.0,96.8,39.3,25.2,43.8,65.4$.

\section{References}

1) Fujiwara Y., Yahara S., Ikeda T., Ono M., Nohara T., Chem. Pharm. Bull., 51, 234-236 (2003).

2) Fujiwara Y., Takaki A., Uehara Y., Ikeda T., Ono M., Yoshimitsu H., Nohara T., Tetrahedron, 60, 4915-4920 (2004).

3) Yahara S., Uda N., Yoshio E., Yae E., J. Nat. Prod., 67, 500-502 (2004).

4) Yahara S., Uda N., Nohara T., Phytochemistry, 42, 169-172 (1996).

5) Ito S., Takahama H., Kawaguchi T., Tanaka S., Iwaki M., J. Phytopathology, 150, 474-480 (2002).

6) Schreiber K., Ripperger H., Liebig's Ann., 655, 114-135 (1962).

7) Schreiber K., "The Alkaloids," Vol. 10, ed. by Manske R. H., Academic Press, New York, 1968, p. 1. 